\title{
¿Objetos, efectos y ganancias del delito como objeto de defraudación tributaria?
}

\section{César Augusto Nakazaki Servigón*}

\section{A manera de introducción}

En el presente trabajo expondremos de manera didáctica los argumentos que en su momento empleamos para la defensa del exgeneral del Ejército, Nicolás Hermoza Ríos, y su familia, en el proceso penal al que fueron sometidos ante la Sala Penal Nacional de la Corte Superior de Lima por el delito de defraudación tributaria. ${ }^{1}$

Sostenemos que los objetos materiales, efectos y ganancias del delito no pueden ser considerados hechos imponibles y, por tanto, no permiten la configuración de la defraudación tributaria. Para arribar a esa conclusión haremos un análisis sistemático de nuestro ordenamiento jurídico, trabajando con el derecho penal, procesal, tributario y civil (patrimonial), único método que permite alcanzar la correcta aplicación de la ley, a fin de enfrentar los fuertes intentos por instaurar en el Perú el empleo del derecho penal del enemigo. ${ }^{2}$

* Agradecemos la colaboración de nuestro asistente Exson Vilcherrez Ato, egresado de la apreciada Facultad de Derecho de la Universidad de Piura, quien viene apoyando intensamente en el plan de producción de obras y artículos que venimos ejecutando.

1 Sala Nacional. Expediente 282-2007, sentencia del 6 de diciembre del 2007.

2 En la justificada lucha contra la corrupción, el crimen organizado, los delitos de lesa humanidad, el terrorismo y el lavado de activos, se han cometido y se come- 
La acusación que se hizo a Nicolás Hermoza y familia fue la siguiente: durante el periodo 1995-2000, los acusados ocultaron dolosamente sus ingresos y rentas a la Administración Tributaria al no declarar el dinero depositado en las cuentas bancarias abiertas en Suiza, ocasionando perjuicio fiscal al Estado por el no pago de impuesto a la renta por la cantidad de S/.11.845.929 (producto de incrementos patrimoniales no justificados y rentas de fuente extranjera). Los hechos fueron tipificados como delito de defraudación tributaria en la modalidad de ocultamiento de ingresos, previsto en el tipo penal complementario de los artículos 268 y 269, inciso 2, del Código Penal (vigente hasta abril de 1996), y en el tipo penal complementario de los artículos 1 y 2, inciso a, del Decreto Legislativo 813, Ley Penal Tributaria (vigente desde abril de 1996).

El proceso penal tuvo como antecedente un proceso administrativo tributario; la Sunat fiscalizó a los contribuyentes, y a pesar de haberse demostrado en la fiscalización que el dinero tenía como origen el peculado y el cohecho pasivo - hasta el punto de que el inicio de la intervención de la Administración Tributaria se dio por comunicación de la juez penal a cargo del proceso penal anticorrupción-, se emitió resolución de determinación de deuda tributaria, que confirmó el Tribunal Fiscal al desestimar la reclamación.

Se promovió un proceso constitucional de amparo, en el cual además se estableció que ya se había dictado sentencia condenatoria por los delitos de peculado y cohecho pasivo propio, e incluso restituido a su propietario, el Estado peruano, la totalidad del dinero depositado en los bancos suizos: capital, intereses y ganancias, por estar en un régimen de trust.

El Tribunal Constitucional emitió una triste sentencia - que no sabemos si reiterará- al sostener, para desestimar el amparo, en esencia,

ten excesos en la aplicación de la ley penal, procesal y de ejecución penal, a través del derecho penal del enemigo, cuya base ideológica es que los procesados y delincuentes por estos delitos no tienen las mismas garantías que los procesados y delincuentes por delitos "comunes", "ordinarios" o "menos graves", a partir de consideraciones como ¡el perder la condición de ciudadanos, personas, al transformarse en demonios, hombres sin derechos, símbolos de castigo! El derecho penal del enemigo se presenta en dos niveles: legislativo y aplicativo; este último es mucho más peligroso, porque el exceso no está en la ley, sino en la aplicación que hacen los operadores jurídicos, con interpretaciones inconstitucionales y sin una seria base dogmático-jurídica. 
que la Sunat no tiene la función de establecer el origen lícito del dinero objeto de las rentas.

El proceso penal por delito tributario terminó desestimando la acusación.

Adelantándonos a las conclusiones, a las que en su momento llegaremos, debemos decir que sostener que esos "ingresos" sí constituían renta significó en su momento, más que un error jurídico grosero por parte de la Sunat, el Ministerio Público, el Poder Judicial (los jueces constitucionales) y el Tribunal Constitucional, una clara aplicación del llamado derecho penal del enemigo. El factor fundamental no fue el derecho, sino el nombre del protagonista de este drama.

\section{La no verificación del elemento típico: bien jurídico}

\subsection{El hecho típico como elemento base de la operación de tipificación}

\subsubsection{El bien jurídico}

El principio de lesividad - límite material de la función punitiva del Estado-, consagrado en la norma IV del título preliminar (principios generales) del Código Penal, determina que el bien jurídico es el factor determinante para establecer cuándo el hecho imputado encuadra en el tipo penal.

Luis Jiménez de Asúa (1992: 449-450) afirma que en las leyes penales la finalidad es el bien jurídico que constituye el objeto de protección del tipo penal, por lo que es forzoso desentrañarlo para efectuar una debida interpretación de la ley penal. El descubrimiento del bien jurídico es el primer paso para aplicar la ley conforme a su sentido a través de su recta interpretación.

Maurach, Gôssel y Zipf (1994: I, 151) señalan que para la interpretación de la ley penal es decisiva la determinación del bien jurídico protegido a través del tipo penal.

Juan Bustos Ramírez (1986: 5) establece que el bien jurídico en la parte especial fija el ámbito del injusto que describe el tipo penal.

Gonzalo Quintero Olivares afirma que el bien jurídico tiene un papel relevante en la interpretación de la ley penal, de allí que es indispensable establecer sus contornos y contenido; es necesario identificar y 
determinar la naturaleza del bien jurídico, para utilizar al objeto jurídico como el "eje interpretativo del precepto penal" (Quintero, Morales y Prats 2000: 151 y 152).

Miguel Polaino Navarrete (2000: 451) acepta que el objeto de tutela penal constituye el "concepto central del tipo según el cual se orientan todas las características objetivas y subjetivas, y con ello integra al propio tiempo un importante instrumento de interpretación" de la ley penal.

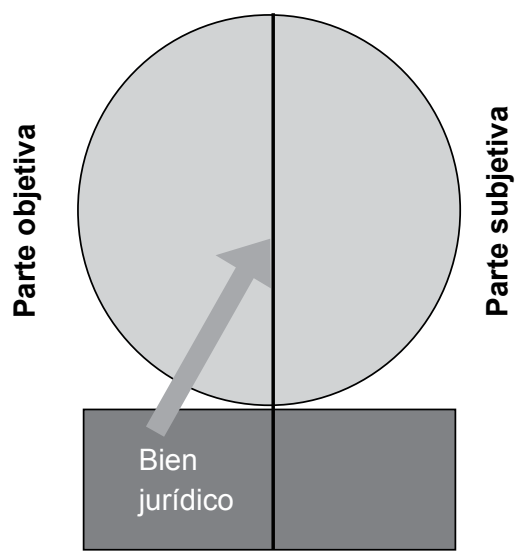

Base típica

2.1.2 El bien jurídico en el tipo penal de defraudación tributaria en la modalidad de ocultamiento de ingresos, previsto en tipo penal complementario de los artículos 268 y 269, inciso 2, del Código Penal (vigente hasta abril de 1996) y en el tipo penal complementario de los artículos 1 y 2, inciso a, del Decreto Legislativo 813, Ley Penal Tributaria (vigente desde abril de 1996) ${ }^{3}$

El Código Penal de 1991 no define; solamente enuncia a los objetos de tutela penal en los títulos del libro segundo. ${ }^{4}$

3 A la fecha -y desde su vigencia-, estos artículos del Decreto Legislativo 813 continúan siendo sustancialmente los mismos, con la salvedad de que en el caso del artículo 1 se agregó, a la pena privativa de la libertad, una pena de multa por la décimo primera disposición final de la Ley 27038, publicada el 31 de diciembre de 1998.

4 Desde que elaboramos la tesis para optar el grado de bachiller, siempre hemos sostenido, con ocasión de desarrollar la teoría del bien jurídico, la necesidad de 
El tipo penal complementario de los artículos 268 y 269, inciso 2, del Código Penal (vigente hasta abril de 1996) pertenecía al título XI, “Delitos tributarios".

El tipo penal complementario de los artículos 1 y 2, inciso a, del Decreto Legislativo 813, Ley Penal Tributaria (vigente desde abril de 1996), corresponde al título I, "Delito tributario".

A diferencia del resto de títulos que integran la parte especial del Código Penal, en el caso analizado ni siquiera se señala al objeto de tutela penal; sin embargo, se establece mediante la dogmática jurídica que se trata del sistema tributario.

En la doctrina nacional, los autores más importantes del derecho penal económico definen el objeto protección penal en los siguientes términos: Manuel Abanto Vásquez (2000: 414-419) afirma que el bien jurídico tutelado "es el funcionamiento de la hacienda pública, cuyos objetos atacados ya de manera directa y comprobable son la consecuencia de ingresos públicos y el empleo de dichos recursos públicos", o el funcionamiento del "sistema de recaudación de ingresos y realización del gasto público"; Percy García Cavero (2007: 604) expresa que se protege la expectativa social de "que el Estado reciba los ingresos generados por los distintos tributos internos". ${ }^{5}$

que en la ley penal -incluida la exposición de motivos - se deben definir los bienes jurídicos. Ver Nakasaki Servigón (1988).

5 Citamos a nuestro apreciado y destacadísimo alumno de la Universidad de Lima porque consideramos que la discusión respecto al objeto de tutela penal - si es el bien jurídico o las expectativas normativas-, que inicia Jakobs y recoge el profesor de la Universidad de Piura, en realidad termina siendo igual que el debate que se dio en torno al contenido del bien jurídico: materialistas o normativistas; análisis unidimensionales del objeto jurídico que, como todo en el derecho, es tridimensional. Referirse a la vida, a la libertad, es expresar la dimensión fáctica del bien jurídico; hacer mención al derecho a la vida, la libertad, es ubicarse en las dimensiones valorativa y normativa. Quienes defienden que el objeto de protección penal son las normas y su expectativa de cumplimiento, no están dejando de lado al bien jurídico, ni su rol en la base típica; simplemente destacan una dimensión de este a partir de la función que asignan a la pena y, por ende, al derecho penal. 
Los autores españoles Miguel Bajo Fernández y Silvina Bacigalupo afirman que el bien jurídico es el patrimonio del Estado, el erario público. ${ }^{6}$

La autora española María Asunción Rancaño Martín (1997: 40 y 41) fija a la hacienda pública como el objeto de tutela penal, la que en su perspectiva objetiva se refiere al patrimonio del erario público, y en la subjetiva se destaca a la hacienda pública como titular de la función financiera y la función tributaria.

En la fórmula típica de defraudación tributaria, en la modalidad de ocultamiento de ingresos, de los artículos 268 y 269, inciso 2, del Código Penal, el bien jurídico se aprecia en el elemento normativo "el impuesto a pagar".

Artículo 269.- Son modalidades de defraudación tributaria y reprimidas con la pena del artículo anterior:

2. Ocultar, total o parcialmente, bienes, ingresos, rentas, frutos o productos o consignar pasivos total o parcialmente falsos, para anular o reducir el impuesto a pagar (cursivas nuestras).

En la fórmula típica de defraudación tributaria, en la modalidad de ocultamiento de ingresos, del artículo 2, inciso a, del Decreto Legislativo 813, el bien jurídico se aprecia en el elemento normativo "el tributo a pagar".

Artículo 2.- Son modalidades de defraudación tributaria y reprimidas con la pena del artículo anterior:

a. Ocultar, total o parcialmente, bienes, ingresos, rentas, o consignar pasivos total o parcialmente falsos para anular o reducir el tributo a pagar $[\ldots]$ (cursivas nuestras).

El bien jurídico protegido es el correcto funcionamiento del sistema tributario, es decir, el aseguramiento de que el Estado perciba los tribu-

6 Bajo Fernández y Bacigalupo (2001: 218); en este sentido, también, Cervini (2010: 184). Opinión distinta es la del profesor español Simón Acosta (1998: 26), para quien el bien jurídico tutelado por los tipos de defraudación tributaria no es el patrimonio del Estado, sino el principio de convivencia social encarnado en el sistema tributario. 
tos que generan las obligaciones tributarias de los contribuyentes por los hechos imponibles definidos en la ley.

El límite de la función punitiva del Estado, principio de protección de bienes jurídicos, exige que existan tributos no pagados para que pueda configurarse el delito de defraudación tributaria (Bacigalupo 2000: 303).

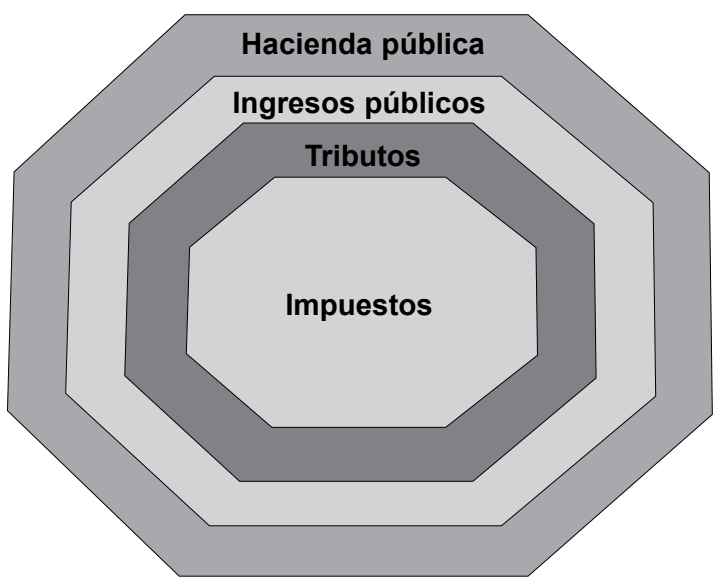

\subsection{Inexistencia de un impuesto a la renta no pagado}

En los hechos que fueron objeto del caso que motiva nuestro análisis no hubo impuesto a la renta no pagado, por dos razones alternativas:

1. O la prohibición de la utilización de la presunción tributaria del artículo 52 de la Ley del Impuesto a la Renta en el proceso penal, por la vigencia de la garantía de la presunción de inocencia.

2. O la equivocada aplicación de la presunción del incremento patrimonial no justificado, porque el objeto del delito de peculado, los efectos del cohecho pasivo propio y las ganancias derivadas de estos ilícitos nunca se incorporaron al patrimonio de los delincuentes.

\subsubsection{La potestad de la Sala Penal de desvincularse de los pronunciamientos} de la Sunat y el Tribunal Fiscal para la determinación del delito

El artículo 7 de la Ley Penal Tributaria establece como condición para el ejercicio de la acción penal por el Ministerio Público, la petición de la parte agraviada, esto es, de la Sunat. 
La petición de la Sunat solamente tiene efecto vinculante respecto del Ministerio Público y no del Poder Judicial, a diferencia, por ejemplo, de la resolución de contenido penal del Congreso, conforme al artículo 100 de la Constitución. ${ }^{7}$

La petición de la Sunat es una condición de la acción penal, no un requisito de mérito para una sentencia condenatoria.

El Tribunal Penal, con total autonomía, debe determinar si en el juicio oral el Ministerio Público ha demostrado que los acusados han cometido delito de defraudación tributaria.

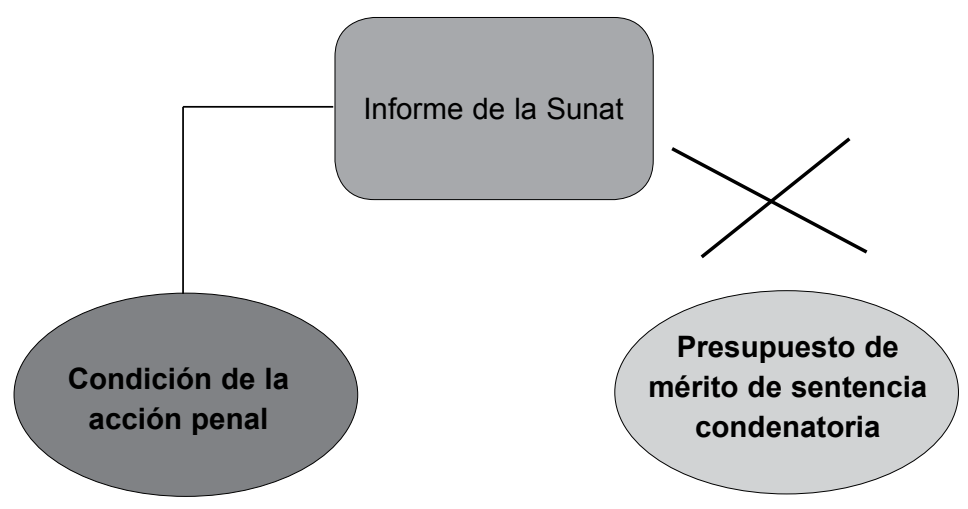

2.2.2 Análisis del método utilizado por la Sunat para establecer la existencia de impuesto a la renta no pagado: la presunción relativa del artículo 52 de la Ley del Impuesto a la Renta

La Sunat determinó la existencia de impuesto a la renta no pagado aplicando el artículo 52 de la Ley del Impuesto a la Renta.

\section{Artículo 52.}

Se presume que los incrementos patrimoniales cuyo origen no pueda ser justificado por el deudor tributario, constituyen renta neta no declarada por este $[\ldots]$.

7 Ello sin perjuicio de la posición que mantenemos sobre la inconstitucionalidad del artículo 100, a partir de su colisión con otras normas de la Ley Fundamental de 1993. Ver Nakasaki Servigón (2003). 
¿Contiene dicho artículo un tipo tributario que define el hecho generador de la obligación de pago del impuesto a la renta?, ¿o contiene una presunción legal relativa que exime a la Administración Tributaria de la prueba del hecho generador?

La respuesta está en el derecho tributario que la Sunat y el Tribunal Fiscal ¡olvidaron! aplicar.

La Ley del Impuesto a la Renta establece una presunción relativa; a partir de la comprobación del hecho base (incremento patrimonial no justificado), la Sunat determinará una renta oculta.

Se trata de una presunción relativa o iuris tantum, esto es, que admite prueba en contrario. Es decir, se reconoce al contribuyente el derecho de probar la falsedad del hecho presumido: la justificación del incremento patrimonial, que "ha sido financiado con rentas no sometidas por cualquier motivo al impuesto" (Nakasaki Servigón 2003: 106 y 107).

La autora española Carolina Blasco Delgado (1997: 113) señala que el incremento patrimonial no justificado es un mecanismo puesto al servicio de la Administración Tributaria, el hecho base de una presunción iuris tantum que permite atribuir al contribuyente "una renta no descubierta ni conocida".

El autor español Ernesto Eseverri Martínez (1995: 49) afirma que la presunción en el caso del impuesto a la renta por incremento patrimonial no justificado impone al interesado el deber de probar la procedencia de las rentas.

En consecuencia, el artículo 52 de la Ley del Impuesto a la Renta no constituye un tipo tributario, esto es, no describe un hecho generador del impuesto a la renta. El incremento patrimonial no justificado no es un hecho imponible, sino una presunción legal que permite determinarlo sin necesidad de prueba.

El hecho generador del impuesto a la renta que se verifica a través de la presunción legal del incremento patrimonial no justificado son las rentas del contribuyente ocultadas a la Administración Tributaria por no haber sido declaradas a pesar de estar gravadas. 
Por ejemplo: el dinero hallado que constituye un incremento no justificado por no haberse declarado por el contribuyente no es el hecho generador del impuesto a la renta; este se presume a partir de aquel y se ubica en alguna de las categorías establecidas en el artículo 22 de la Ley del Impuesto a la Renta, en el que se describen los tipos tributarios.

\begin{tabular}{|c|c|}
\hline Categorías del impuesto a la renta & Hecho generador de la renta \\
\hline Primera categoría & $\begin{array}{l}\text { - Rentas producidas por el arrenda- } \\
\text { miento, subarrendamiento y } \\
\text { cesión de bienes. }\end{array}$ \\
\hline Segunda categoría & - Rentas de otros capitales. \\
\hline Tercera categoría & $\begin{array}{l}\text { - Rentas del comercio, la industria y } \\
\text { otras expresamente consideradas } \\
\text { por la ley. }\end{array}$ \\
\hline Cuarta categoría & - Rentas del trabajo independiente. \\
\hline Quinta categoría & $\begin{array}{l}\text { - Rentas del trabajo en relación de } \\
\text { dependencia y otras rentas del } \\
\text { trabajo independiente expresa- } \\
\text { mente señaladas en la ley. }\end{array}$ \\
\hline
\end{tabular}

Blasco Delgado (1997: 112), Jiménez Compaired (1996: 106) y Eseverri Martínez (1995: 75-78) señalan con claridad que los incrementos patrimoniales no justificados no son renta gravable, sino simplemente el hecho base de una presunción iuris tantum por la que se atribuye al sujeto pasivo una renta no descubierta ni conocida. 

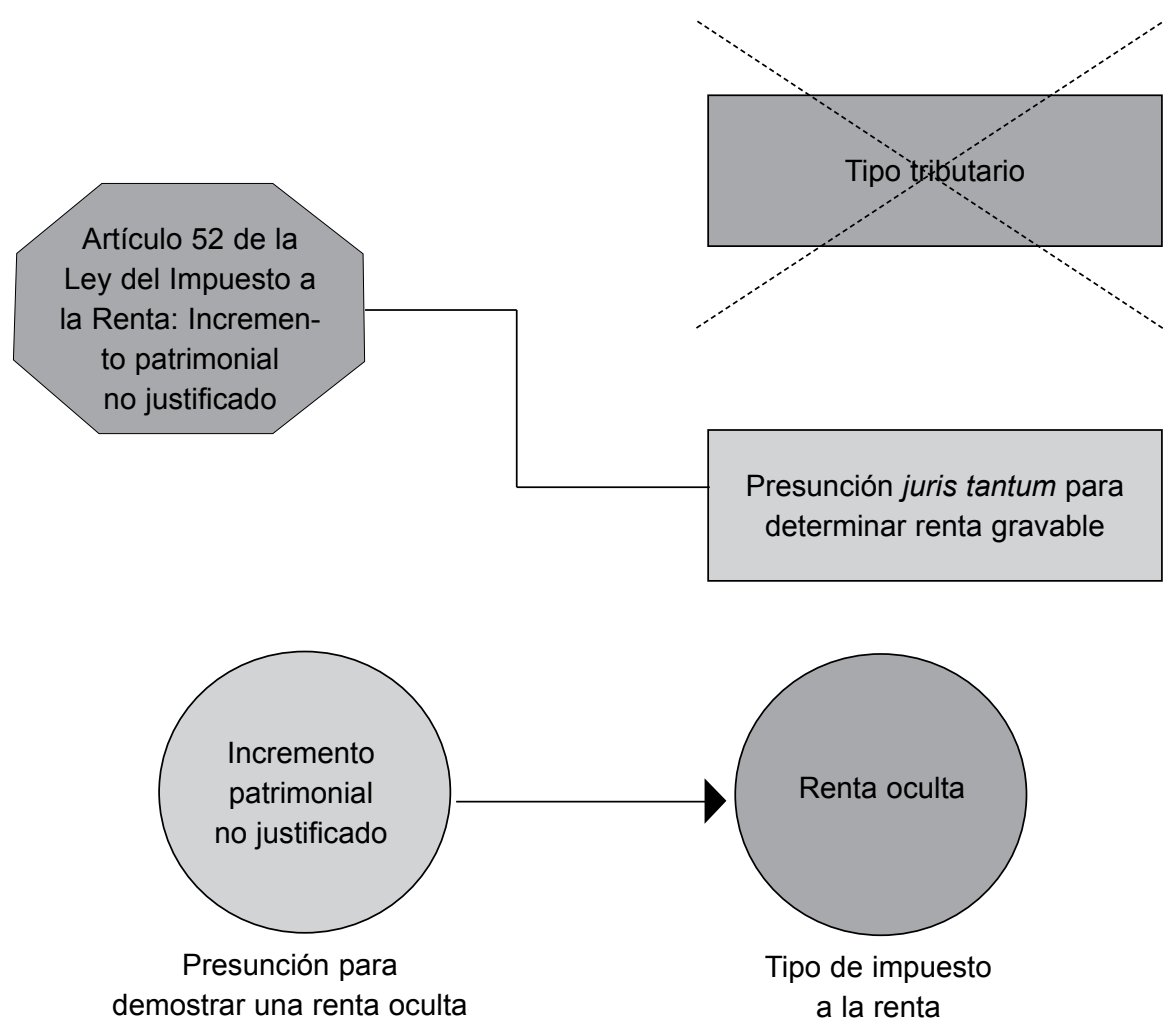

2.2.3 La prohibición de la utilización de la presunción tributaria del artículo 52 de la Ley del Impuesto a la Renta en el proceso penal, por la vigencia de la garantía de la presunción de inocencia

La llamada presunción de inocencia constituye el derecho fundamental del acusado de un delito a que se le presuma inocente mientras no se pruebe su culpabilidad en un debido proceso penal.

El derecho a la presunción de inocencia se encuentra garantizado por el artículo 11, inciso 1, de la Declaración Universal de Derechos Humanos; el artículo 14, inciso 2, del Pacto Internacional de Derechos Civiles y Políticos; el artículo XXVI, primer párrafo, de la Declaración Americana de los Derechos y Deberes del Hombre; el artículo 8, inciso 2, de la Convención Americana sobre Derechos Humanos; y el artículo 2, inciso 24, parágrafo e, de la Constitución Política del Perú.

El maestro español Juan Montero Aroca (1997: 151-156) señala que una manifestación de la presunción de inocencia es la exigencia de que 
la culpabilidad del acusado sólo se demuestre mediante prueba producida en el proceso penal, prueba que alcanza a todos los elementos del hecho delictivo; es decir, cada uno de los elementos del delito tiene que ser probado para justificar la sentencia condenatoria de la persona acusada.

El autor español Miguel Ángel Montañés Pardo (1999: 81 y 82) explica que la primera manifestación de la presunción de inocencia es un desplazamiento de la carga de la prueba a las partes acusadoras, a quienes corresponde probar los elementos constitutivos de la acusación; si todo acusado se presume inocente hasta que sea condenado, es lógico que la presunción de inocencia incida en las reglas de distribución de la carga de la prueba: corresponde a la acusación y no a la defensa la realización de la actividad probatoria que se necesita para desvanecer la presunción de inocencia.

Por último, César San Martín Castro (2003: 114-116) - presidente del Poder Judicial - , en la misma línea, reconoce el derecho a la presunción de inocencia como garantía de que la persona, en el proceso penal, será considerada inocente del delito imputado mientras no se presente prueba bastante para destruir dicha presunción. Igualmente asume, siguiendo la doctrina judicial española, que la necesidad de prueba se refiere a todos los hechos descritos en el tipo penal.

Es evidente que el derecho a la presunción de inocencia garantiza que en el proceso penal por delito de defraudación tributaria en la modalidad de ocultamiento de ingresos, el elemento típico "impuesto a la renta no pagado" sea demostrado a través de prueba; es decir, que el hecho que forma este elemento normativo: renta gravable del deudor tributario, sea probado en el proceso penal.

No es admisible en el proceso penal, por tanto, que la renta gravada sea demostrada mediante una presunción legal relativa como la del artículo 52 de la Ley del Impuesto a la Renta. Las presunciones tributarias no pueden reemplazar a la prueba en el proceso penal.

Abanto Vásquez (2000: 427), al sostener que algunas instituciones del derecho tributario no pueden ser utilizadas en el derecho penal, se refiere específicamente a la presunción tributaria por incremento patrimonial no justificado; sostiene, con firmeza, que la presunción tributaria de incremento patrimonial "no debe tener efectos penales", porque signifi- 
caría una violación de la presunción de inocencia al implicar una prohibida inversión de la carga de la prueba.

Bajo Fernández y Bacigalupo (2001: 214) señalan que las presunciones tributarias no pueden ser utilizadas en el proceso penal porque son incompatibles con la garantía de la presunción de inocencia: "[...] en el procedimiento penal no es posible operar con presunciones legales aunque admitiesen la prueba en contrario, porque implican una inversión de la carga de la prueba", conforme lo ha establecido el Tribunal Constitucional español a partir de su sentencia del 26 de abril de 1990.

Desde el derecho tributario también se impone el reconocimiento de la no utilización de la presunción del incremento patrimonial no justificado en el proceso penal; así, Jiménez Compaired resalta la doctrina judicial española que entiende el rechazo del injerto de la presunción tributaria para establecer la culpabilidad de una persona por la comisión de un delito. Se fundamenta esto en la no aceptación en la inversión de la carga material de la prueba, inadmisible en el caso penal por la vigencia del derecho fundamental a la presunción de inocencia (1996: 251).

En igual sentido, el tributarista Eseverri Martínez (1995: 127-139) afirma que para el juez penal el valor superior de la presunción de inocencia le exige desvincularse de la determinación de hechos por parte de la Administración Tributaria utilizando presunciones; expresa que es inaceptable acreditar hechos, de los que se puede derivar una pena privativa de la libertad, empleando presunciones tributarias que sustituyan pruebas.

La garantía de la presunción de inocencia tiene tal fortaleza en el Estado de derecho que ninguna determinación de hechos a partir de presunciones tributarias puede sustentar una sentencia condenatoria en el proceso penal (Eseverri Martínez 1995: 127-139).

Esta prohibición de emplear la presunción tributaria del artículo 52 de la Ley del Impuesto a la Renta en el proceso penal fue transgredida por el Ministerio Público en el momento de sustentar su acusación contra Nicolás Hermoza Ríos y su familia, por la supuesta comisión del delito de defraudación tributaria. 


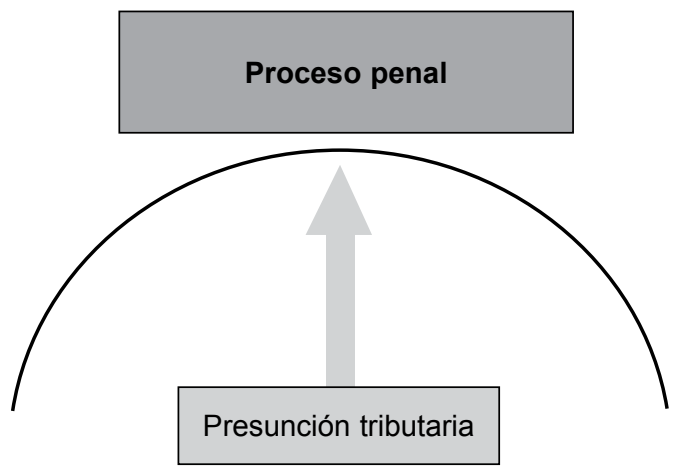

2.2.4 La equivocada aplicación de la presunción del incremento patrimonial no justificado, porque el objeto del delito de peculado, los efectos del cohecho pasivo propio y las ganancias derivadas de estos ilícitos nunca se incorporaron al patrimonio de los delincuentes

Si bien ya descartamos en el apartado anterior la aplicación de la presunción del incremento patrimonial al proceso penal, por la vigencia de la garantía a la presunción de inocencia, agregaremos a ello la imposibilidad, siquiera, de aplicarla en el ámbito tributario.

A. Estructura de la presunción legal del incremento patrimonial no justificado

\section{A.1 El hecho base}

Es la incongruencia entre un incremento en el patrimonio del contribuyente y sus medios declarados (Eseverri Martínez 1995: 110). Se trata de un hecho complejo formado por dos elementos (Eseverri Martínez 1995: 112):

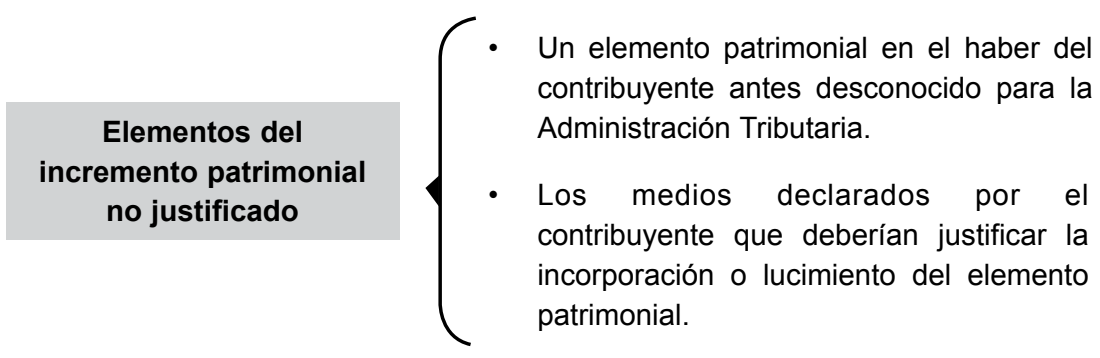


La verificación del primer elemento exige poder imputar el bien a una persona por ser su titular; si no se establece la relación entre el elemento patrimonial y el contribuyente, la Administración Tributaria no podrá utilizar la presunción legal (Eseverri Martínez 1995: 120).

Blasco Delgado (1997: 115) define el incremento patrimonial como una variación del patrimonio del contribuyente o sujeto pasivo, y precisa que está conformado por dos elementos positivos y uno negativo:

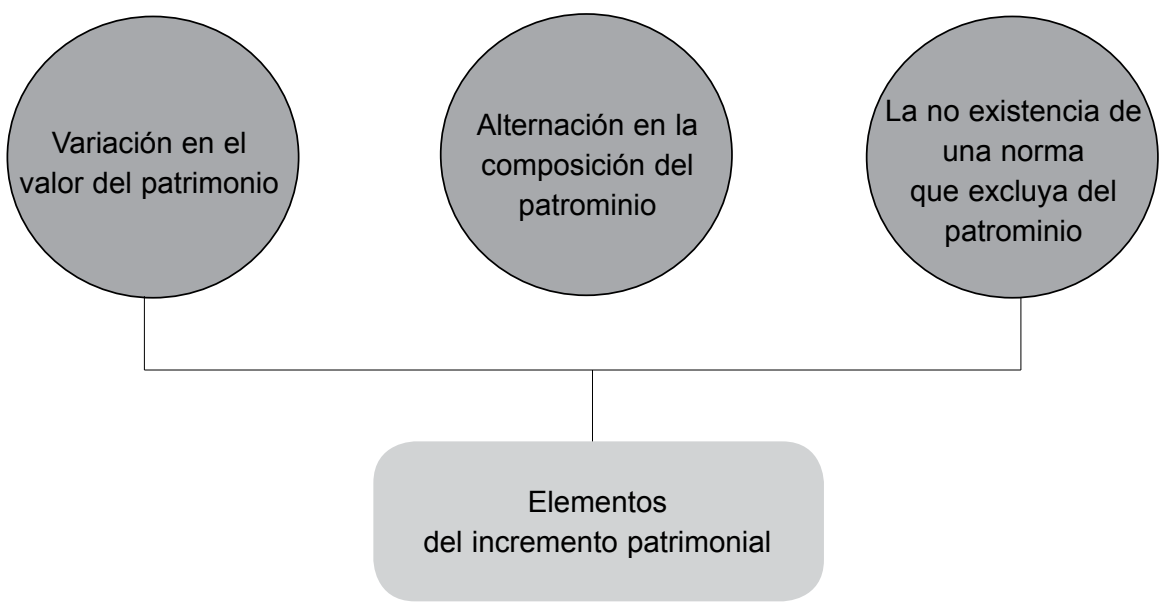

Para la utilización de la presunción legal del incremento patrimonial no justificado es indispensable tener definido con claridad el concepto de patrimonio, fundamentalmente para verificar el elemento negativo: la no existencia de una norma legal que excluya del patrimonio del contribuyente a los bienes ocultos y no declarados.

Existe una coincidencia sustancial entre el concepto de patrimonio del derecho civil y el de patrimonio en el derecho tributario; en este último ámbito se le define como "el conjunto de bienes, derechos y obligaciones esencialmente transmisibles de los que es titular una persona -o que están adscritos a un determinado fin-, que conservan su individualidad material aunque pueden ser contemplados unitariamente, y que son económicamente cuantificables" (Blasco Delgado 1997: 124). 


\section{A.2 El hecho presunto}

Comprobado el hecho base, se presume la realización del hecho presunto: el supuesto típico establecido en la norma tributaria que se pretende aplicar, en este caso, la obtención de renta oculta no declarada pese a estar afecta al impuesto a la renta (Blasco Delgado 1997: 177).

Sin embargo, dado que, como se reitera, se trata de una presunción legal o iuris tantum, es posible demostrar que el hecho presunto no se ha producido, que no existen rentas no declaradas sujetas al impuesto a la renta.

Jiménez Compaired precisa correctamente que el hecho presunto no es la obtención y no declaración de rentas en sentido económico, sino en sentido jurídico: "rentas fiscales que deben someterse al impuesto" (1996: 178).

El contribuyente puede probar que no existen rentas ocultas, porque el bien o dinero que la Administración Tributaria ha detectado como incompatible con la declaración jurada de impuesto a la renta fue financiado de cualquiera de dos maneras:

- Por medios propios no declarados porque no se encuentran afectos al impuesto a la renta.

- Por medios ajenos que no se conocieron al momento de la fiscalización de la declaración del contribuyente.

Eseverri Martínez (1995: 78) precisa que la presunción se extiende hasta la verificación de que el patrimonio del contribuyente ha aumentado, cuando se comprueba un incremento patrimonial que sólo será gravable si resulta injustificado, pues si resulta justificado no resultará hecho imponible del impuesto a la renta.

B. La presunción legal solo es aplicable cuando la Administración Tributaria detecta un incremento patrimonial: el objeto del delito de peculado, los efectos del delito de cohecho pasivo propio y las ganancias provenientes del peculado y el cohecho no constituyen incremento patrimonial del contribuyente

La presunción relativa del artículo 52 de la Ley del Impuesto a la Renta solamente funciona cuando la Administración Tributaria detecta un incremento patrimonial del contribuyente que no puede justificar. 
La utilización de la presunción legal exige considerar si el dinero depositado en los bancos suizos, a pesar de provenir del peculado y el cohecho, ingresó al patrimonio de los contribuyentes-delincuentes, es decir, si puede ser calificado como un incremento patrimonial.

Se tiene que valorar si el dinero resultó objeto, efecto o ganancia del delito, y si estos ingresan al patrimonio del delincuente. Lamentablemente, en el proceso penal que motiva este artículo, ni la Sunat ni el Ministerio Público efectuaron este indispensable análisis jurídico, a pesar de conocer que los depósitos en las cuentas bancarias suizas de Nicolás Hermoza Ríos y su familia provenían de los delitos de peculado $\mathrm{y}$ cohecho pasivo propio.

B.1 ¿Los objetos, efectos y ganancias del delito constituyen renta del contribuyente?

Sólo el dinero que haya ingresado al patrimonio del contribuyente puede ser renta. Los objetos, los efectos y las ganancias del delito no ingresan al patrimonio del delincuente, por lo que no pueden ser considerados como hechos imponibles generadores del impuesto a la renta.

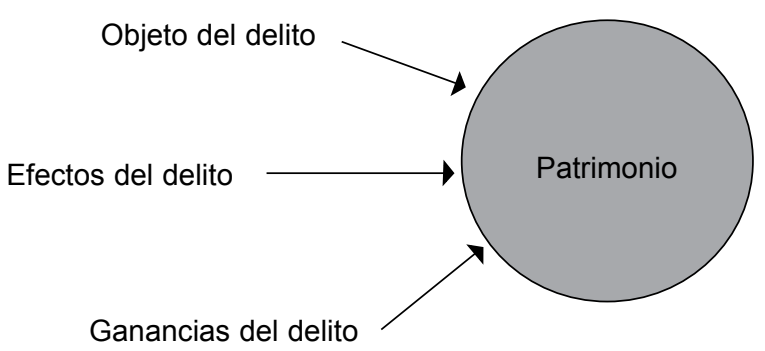

\section{B.1.1 Los objetos del delito}

El maestro español Luis Jiménez de Asúa (1992b: 111 y 112) definía el objeto material o de la acción, como toda persona o cosa que forma parte del tipo descrito en la ley.

Los objetos del delito no son objeto de decomiso (Maurach, Gôssel y Zipf 1994: II), sino de reparación civil, ya que por lo general pertenecen a la víctima, de allí que tengan que ser restituidos a su propietario y no confiscados por el Estado, pues es obvio que al sujeto pasivo no se le va a jcastigar quitándole sus bienes por haber sido afectado por un delito! 
Los objetos del delito no ingresan al patrimonio del delincuente; por el contrario, pertenecen a otro: la víctima.

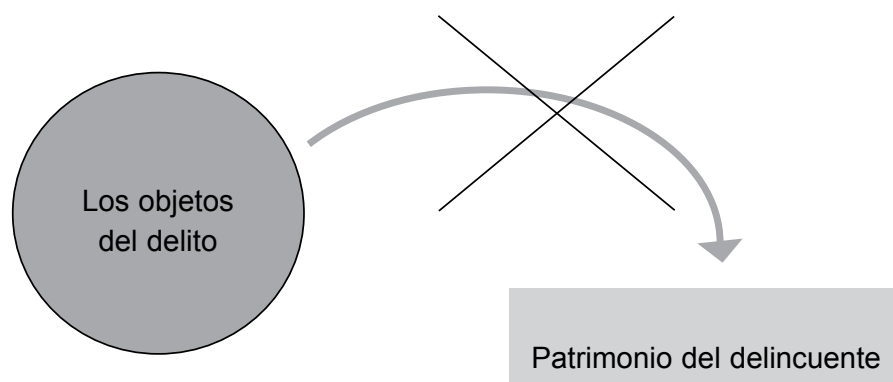

\section{B.1.2 Los efectos del delito}

El autor argentino Eugenio Zaffaroni (1983: 264) afirma que los efectos del delito son los objetos que el delincuente obtiene con la realización de la conducta típica.

El autor español Luis Gracia Martín (2004: 301; 2000: 398) expresa que son efectos del delito "los objetos que hayan sido producidos mediante la acción delictiva".

José Luis Castillo Alva (2001: 211), en la misma línea, señala que los efectos del delito son los objetos que constituyen el resultado del delito.

Los efectos del delito no deben confundirse con los objetos del delito; de allí que, a diferencia de estos últimos, los primeros sí son objeto de decomiso (Zaffaroni 1983: 265; Castillo Alva 2001: 211).

Gracia Martín (2004: 301; 2000: 398) advierte que los objetos del delito no pueden ser considerados efectos, ni decomisados, sobre todo porque en la mayoría de casos pertenecen a la víctima.

Según los autores españoles Jaime Miguel Peris Riera y Cristina Pla Navarro, son efectos del delito "los que se encuentren en poder del delincuente y que hayan sido producidos mediante la acción delictiva o sean consecuencia de la misma, sin que abarque a los que constituyen el objeto mismo de la infracción" (2000: 962). 
Los efectos del delito tampoco llegan a incorporarse al patrimonio del delincuente, por su causa u origen ilícito.

El artículo 102 del Código Penal establece el ámbito de aplicación de la consecuencia accesoria del decomiso, en el cual de manera expresa se señala a los efectos del delito.

Un claro ejemplo de lo sostenido se tiene en el artículo 401 A: los sobornos no son objeto de medida cautelar de embargo para que sirvan al pago de la reparación civil, pues solo los bienes del delincuente sirven para tal finalidad; los sobornos, como ingresan al patrimonio del condenado, son incautados y luego decomisados.

Para la adquisición de la propiedad de los bienes se tiene que aplicar las reglas del Código Civil, pues el Código Penal no regula esta materia.

El Código Civil de 1984, en el libro V ("Derechos reales"), sección tercera, título II, capítulo segundo, contiene las reglas de la adquisición de la propiedad; en el artículo 947 está la regla para la transferencia de la propiedad de bienes muebles:

Artículo 947.- Transferencia de propiedad de bien mueble.

La transferencia de propiedad de una cosa mueble determinada se efectúa con la tradición a su acreedor, salvo disposición legal diferente (cursivas nuestras).

El legislador de 1984 determina dos elementos para la transmisión de la propiedad mueble:

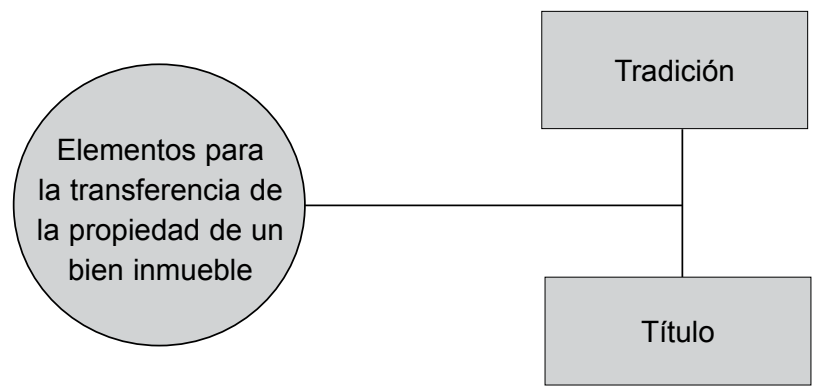


Beatriz Boza Dibós, comentando el artículo 947 del Código Civil, afirma que se basa en el derecho francés, que exige para la transferencia de la propiedad mueble la llamada tradición causal; esto es, que la propiedad de un bien mueble se transmite si se cumple no solo con el requisito de la tradición, la entrega de la cosa, sino que además "supone la existencia de un título y de un modo válidos" (1989: 200 y 201).

Para la adquisición de la propiedad mueble debe existir un título o acto de naturaleza obligatoria que dé lugar a una obligación de dar que se pague con la tradición de la cosa. Apunta inteligentemente Boza Dibós (1989: 200) que el legislador de 1984 no se refiere al adquiriente, sino al acreedor, siendo este término el fundamento del elemento causal en la adquisición de la propiedad mobiliaria.

Guillermo Borda (1984: 304), el gran maestro argentino, señala igualmente la necesidad de que se verifiquen la tradición y el título - que él denomina "el acuerdo de voluntades" - para que opere la transferencia de la propiedad mueble.

Cuando el delincuente obtiene los efectos del delito no adquiere la propiedad, así los reciba del propietario - por ejemplo, en la apropiación ilícita - y que por tanto se considere que operó la tradición; en este caso no habrá el título o causa que produzca la transmisión del dominio, pues el ilícito penal no puede ser considerado como tal.

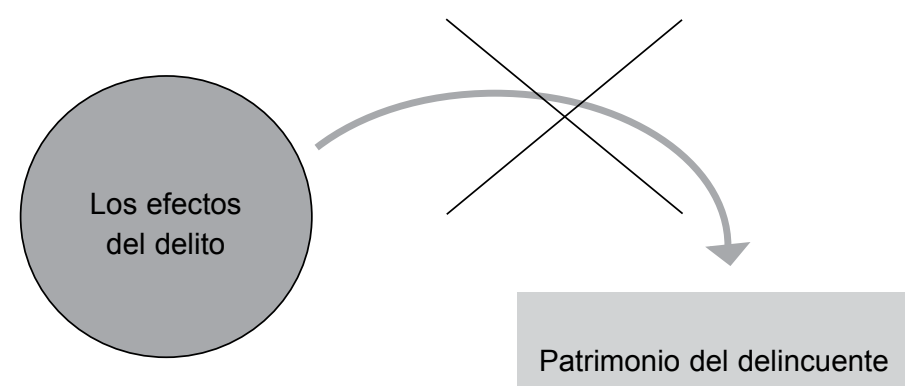




\section{B.1.3 Las ganancias del delito}

Son las ventajas económicas o patrimoniales obtenidas de la infracción delictiva (Peris Riera y Pla Navarro 2000: 962).

Luis Gracia Martín (2004: 304; 2000: 400) define a las ganancias como los provechos o beneficios, no necesariamente económicos, que produce el delito.

Las ganancias provenientes del delito no llegan a formar parte del patrimonio del delincuente porque la ley prohíbe el enriquecimiento sin causa o injustificado, conforme se establece en el artículo 1954 del Código Civil y en las distintas normas que se encuentran en la base típica de los delitos contra el patrimonio particular (por ejemplo, apropiación ilícita o estafa) y el patrimonio estatal (por ejemplo, peculado o cohecho).

El maestro español Luis Díez-Picazo (1996: 89-90) afirma que el derecho civil patrimonial regula que el intercambio de bienes y servicios sólo sea consecuencia de negocios jurídicos lícitos y válidamente celebrados, o de actos realizados con arreglo a los preceptos legales; de allí que todo desplazamiento patrimonial, todo enriquecimiento y en general toda atribución patrimonial, para ser lícitos, deben fundarse en causas que el ordenamiento legal considere como justas.

El mismo Díez-Picazo (1996: 90) señala que cuando la atribución patrimonial -incluyendo el desplazamiento y el enriquecimiento- no está fundada en una justa causa, el beneficiario de la atribución debe restituir al atribuyente el valor del enriquecimiento, quien además tiene una acción de restitución.

El fundamento de la acción por enriquecimiento sin causa es el contar con un mecanismo de control "causal funcional" de las atribuciones y desplazamientos patrimoniales (1996: 99).

El maestro italiano Francesco Messineo (1971: 495) enseña que el enriquecimiento sin causa se da en aquellos casos en los que alguien se beneficia con un bien o actividad ajena, sin que exista una justificación legal para ello; falta una relación jurídica constituida que legitime el beneficio o el provecho.

El maestro argentino Guillermo Borda (1984: 513-514) explica que los desplazamientos patrimoniales, el traspaso de bie- 
nes de una persona a otra, debe tener una causa o razón jurídica; de allí que se prohíba que uno pueda enriquecerse a costa del empobrecimiento de otro sin motivo legítimo.

Las ganancias del delito no llegan a incorporarse al patrimonio del delincuente porque configuran un enriquecimiento sin causa; en el ordenamiento jurídico no se le reconoce al autor del delito la condición de propietario o acreedor respecto de las ganancias que obtuvo por la comisión de ilícitos penales.

Por tal razón, las ganancias del delito son objeto de decomiso conforme al artículo 102 del Código Penal.

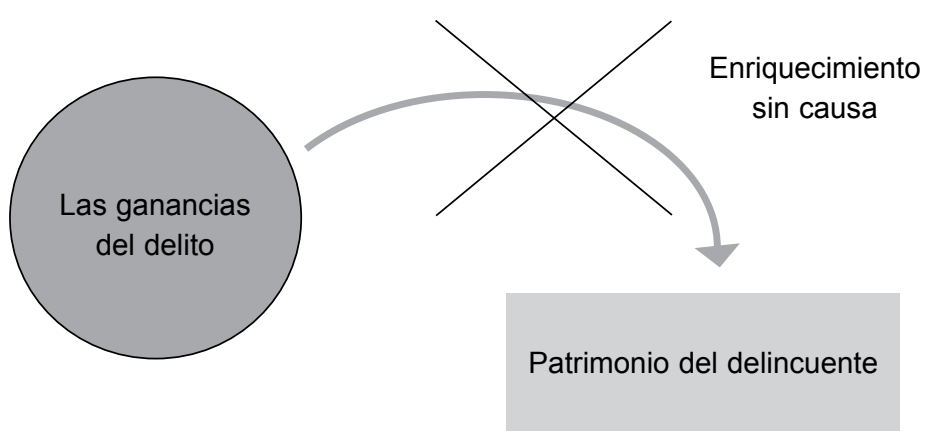

B.2 ¿El objeto del peculado y los efectos del cohecho pasivo propio que Nicolás Hermoza Ríos y familia obtuvieron mediante la comisión de los delitos de peculado y cohecho pasivo propio pudieron configurar incremento patrimonial no justificado para la determinación del impuesto a la renta mediante la presunción del artículo 52?

En la sentencia expedida por la Tercera Sala Penal Superior Especial, de 16 de mayo del 2005, se concluyó que el dinero objeto de las cuentas bancarias abiertas en Suiza fue consecuencia de la comisión de los delitos de peculado y cohecho pasivo propio en agravio del Estado peruano. 


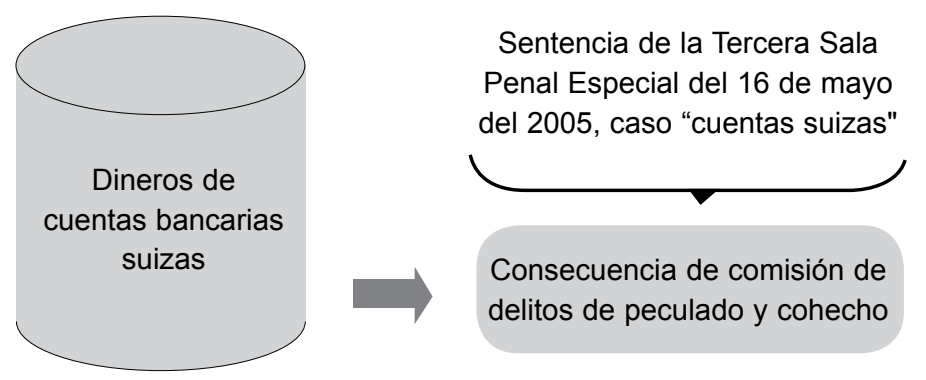

B.2.1 El dinero obtenido por el peculado no ingresó al patrimonio de los contribuyentes porque fue objeto del delito

El Poder Judicial determinó que el dinero que obtuvo Nicolás de Bari Hermoza Ríos por la comisión del peculado fue objeto del delito; no propiedad del delincuente, sino del Estado. Se trató de fondos públicos sobre los que recayó la acción de apoderamiento por violación de los deberes de función como comandante general del Ejército.

Los fondos públicos que son el objeto de acción del peculado no ingresaron al patrimonio de los contribuyentes. De allí que la Sunat incurrió en gravísimo error cuando, empleando la presunción del artículo 52 de la Ley del Impuesto a la Renta, determinó que constituyeron renta gravada no declarada de los inculpados, pues, como se reitera, el dinero de las cuentas bancarias de Suiza nunca ingresó al patrimonio de los "contribuyentes"; estos jamás fueron propietarios del mismo.

Es un absurdo jurídico pretender que un particular pague impuesto a la renta por fondos públicos, es decir, por dinero del Estado, máxime si aquel los obtuvo cometiendo un delito.

El objeto del peculado no debe quedar con el que cometió peculado; hay que quitárselo, pero no haciéndole pagar impuesto a la renta por los fondos públicos, sino decomisándolo. 


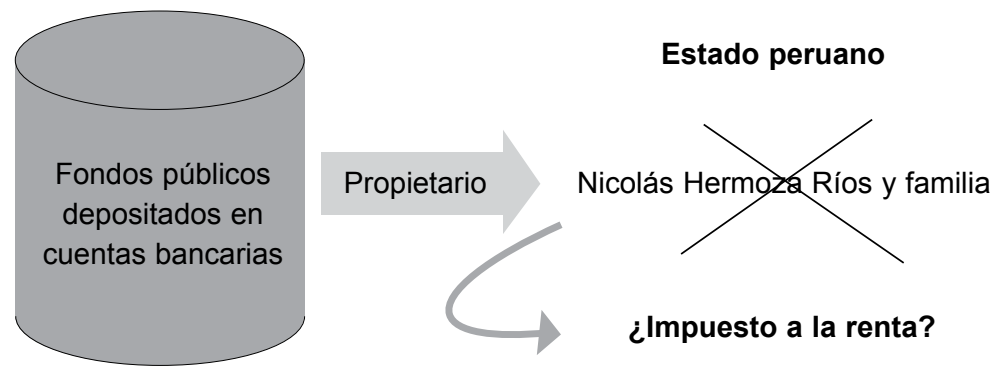

B.1.2 El dinero obtenido por el cohecho pasivo propio no ingresó al patrimonio de los contribuyentes porque constituyó efecto del delito

El dinero que se obtuvo por la comisión de cohecho pasivo propio fue efecto del delito y, por tanto, no llegó a ser propiedad del corrupto, ni de sus cómplices, a pesar de habérselo entregado el propietario-corruptor, en este caso: los comerciantes de armas que entregaron sobornos al excomandante general del Ejército.

El soborno no ingresa al patrimonio del corrupto por la falta de título o causa; el acuerdo de corrupción no produce la transmisión de propiedad del dinero del corruptor al corrupto.

El corrupto es un poseedor vicioso porque adquiere la posesión del soborno mediante evidente infracción de la ley penal: la perpetración del delito de cohecho pasivo propio.

La propiedad del dinero objeto del soborno, al no llegar a ser transferida al corrupto, sigue siendo del corruptor, el mismo que la pierde por decomiso: el Estado adquiere el dominio por la aplicación de la consecuencia accesoria del delito establecida en el artículo 102 del Código Penal.

El dinero logrado por soborno tampoco puede constituir renta que permita a la Sunat determinar una deuda tributaria exigible, ya que, al igual que en el caso del peculado, no ingresó al patrimonio de los acusados porque nunca llegaron a ser los propietarios.

Los efectos de la corrupción pasiva de funcionario público no deben quedar con el corrupto; hay que quitárselos, pero no 
haciéndole pagar impuesto a la renta por los sobornos, sino decomisándolos.

En la lógica sostenida, el 24 de enero del 2002, la juez del Segundo Juzgado Penal Anticorrupción, en el proceso penal ordinario por los delitos de peculado y cohecho pasivo propio seguido a la familia Hermoza Ríos, dictó auto de incautación de US\$20.550.000,00, más intereses legales a liquidarse, que se encontraban depositados en el banco privado Edmond de Roschild Sociedad Anónima y en el Banco UBS AG Bank de Lugano, en Ginebra, Suiza.

La incautación del dinero depositado en las cuentas suizas fue realizada en aplicación del artículo 5 del Decreto de Urgencia 122-2001, que dispone la incautación "del dinero mal habido", esto es, de las sumas de dinero que, tratándose de objetos, efectos o instrumentos de delito en agravio del Estado, corresponden ser decomisados a favor de este último.

El 23 de noviembre del 2003, el Segundo Juzgado Penal Especial de Lima dispuso el decomiso y la transferencia de US\$21.155.173,55, más intereses, a favor del Fondo Especial de Administración del Dinero Obtenido Ilícitamente en perjuicio del Estado (Fedadoi), mediante el endose del certificado de depósito judicial 2002422204238.

El íntegro del dinero obtenido por la comisión del peculado y el cohecho pasivo propio fue entregado en propiedad al Estado peruano, previo allanamiento y realización de todos los trámites por los procesados.

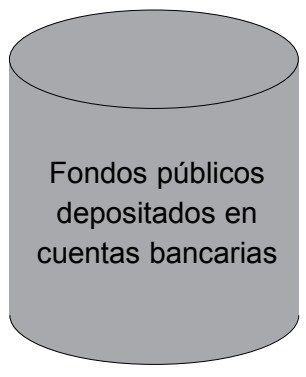

\section{Estado peruano}
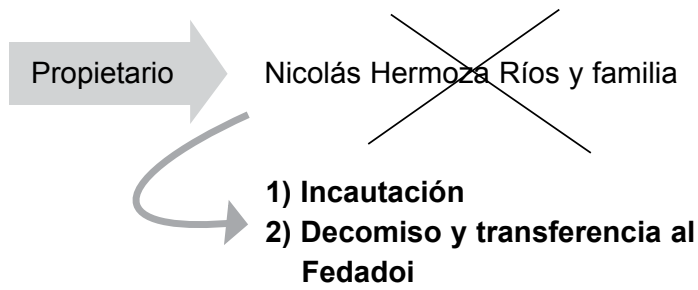
B.3 ¿Las ganancias ilícitas que Nicolás Hermoza y su familia obtuvieron mediante la comisión de los delitos de peculado y cohecho pasivo propio pueden configurar renta por fuente extranjera?

Para la determinación del "impuesto a la renta no pagado", la Administración Tributaria diferenció el capital de los intereses y las ganancias; al primero lo consideró renta por incremento patrimonial no justificado; al segundo y al tercero, rentas de fuente extranjera.
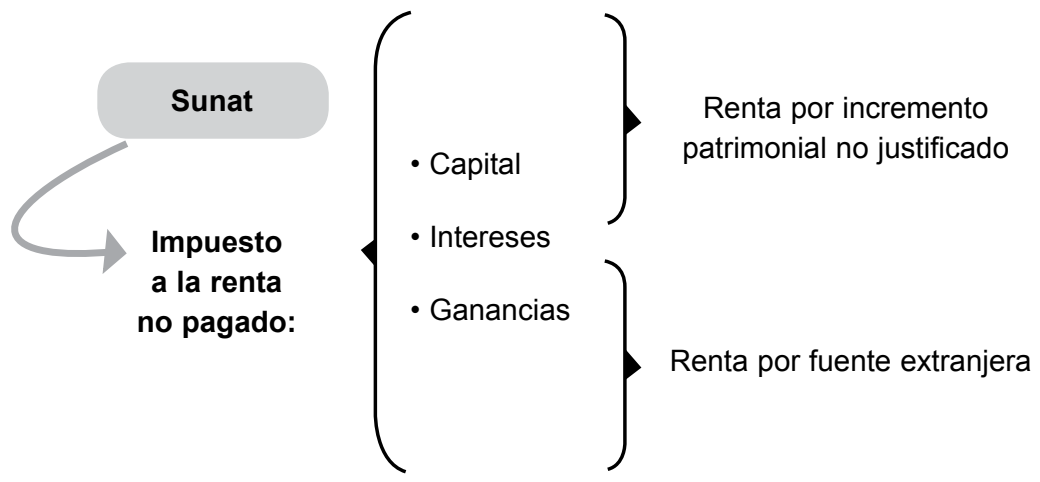

Una vez demostrado el error de utilizar la presunción de incremento patrimonial no justificado, ahora toca demostrar el equívoco que significó considerar a las ganancias ilícitas del peculado y el cohecho como intereses y ganancias lícitas constituyentes de renta de fuente extranjera.

Los intereses, las ganancias de capital y los resultados de inversión no son ni objeto ni efectos: constituyen las ganancias del delito.

En el apartado B.1.3 se definió a las ganancias del delito como las ventajas económicas o patrimoniales obtenidas de la infracción delictiva. No llegan a integrar el patrimonio del delincuente por la prohibición del enriquecimiento sin causa.

El enriquecimiento sin causa determina que a pesar de que exista la tradición, no opera la transmisión de la propiedad del dinero, pues falta título, conforme se explicó en el apartado B.1.2 al tratar los efectos del delito. 
Los intereses, ganancias de capital y resultados de inversión que genera el "capital" obtenido por el peculado y el cohecho pasivo, configuran enriquecimiento sin causa; los contribuyentes no llegan a ser propietarios, sino poseedores viciosos.

El artículo 910 del Código Civil establece que el poseedor de mala fe no adquiere el dominio de los frutos, en este caso civiles (los intereses, las ganancias de capital y los resultados de inversión), frutos que tiene la obligación de restituirlos a su propietario.

Los frutos civiles del "capital" (dinero depositado), esto es, los intereses, las ganancias de capital y los resultados de inversión - abonados en las cuentas de los bancos suizos -, fueron restituidos a su propietario, el Estado peruano, mediante el auto de decomiso del 21 de noviembre del 2003.

Las ganancias ilícitas provenientes del peculado y la corrupción pasiva de funcionario público no deben quedar con el delincuente; hay que quitárselas, pero no haciéndole pagar impuesto a la renta por ellas, sino decomisándolas.

Como ya se mencionó, el 23 de noviembre del 2003, el Segundo Juzgado Penal Especial de Lima dispuso el decomiso y la transferencia de US\$21.155.173,55 a favor del Estado, lo que significó también la entrega en propiedad, a este, de las ganancias ilícitas.

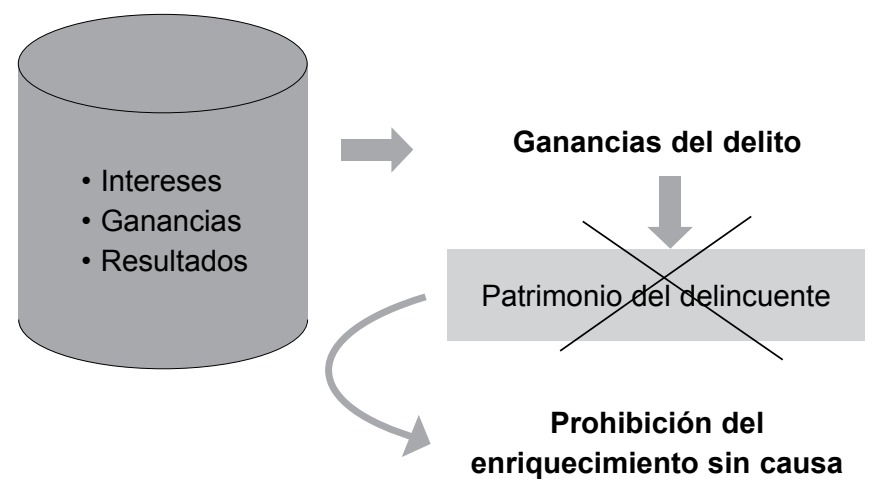


2.2.5 La finalidad de la limitación probatoria es impedir que el contribuyente se beneficie empleando utilidades ilícitas para dejar de pagar impuestos: los contribuyentes invocaron el origen delictivo del dinero no para beneficiarse, sino para hacer ver a la Administración Tributaria que ya habian sido sancionados penalmente por su obtención y lo habían restituido a su propietario

La limitación probatoria del artículo 52 de la Ley del Impuesto a la Renta tiene por función impedir que el contribuyente emplee la utilidad obtenida mediante elusión o evasión tributaria para justificar un incremento patrimonial.

Es importante considerar que el legislador emplea en el mencionado artículo el término utilidades, evidenciando que lo hace en sentido técnico, pues a lo largo del articulado de la Ley del Impuesto a la Renta emplea los términos ingresos, intereses, dividendos, etc.

La limitación probatoria es aplicable en casos de dinero que sí ha ingresado al patrimonio del contribuyente, por haber operado la tradición con un título, pero que es ocultado mediante la elusión o la evasión.

En las fiscalizaciones y en los procesos contenciosos tributarios, los contribuyentes no argumentaron que el dinero depositado en los bancos suizos no constituían rentas gravables por ser objeto, efecto y ganancia de los delitos de peculado y cohecho pasivo propio, para beneficiarse evitando el pago de impuesto a la renta, sino más bien lo hicieron para hacer conocer a la Sunat que el dinero no formaba parte del patrimonio de los contribuyentes, sino del Estado del Perú, y que por su percepción ilícita serían $-\mathrm{y}$ así lo fueron- sancionados penalmente y, en consecuencia, aquel sería restituido a su propietario.

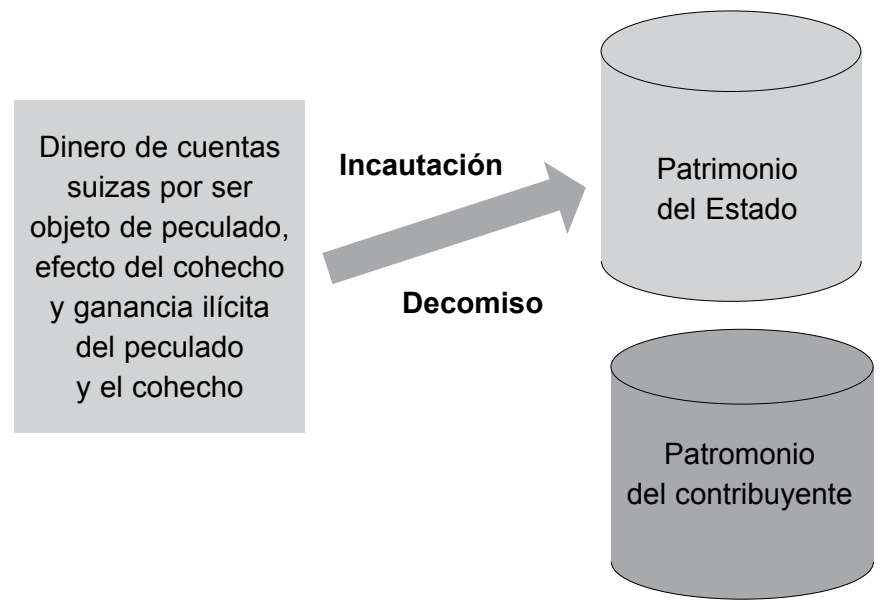


2.2.6 La prohibición de emplear una presunción para establecer un hecho que ha sido determinado ya en una resolución judicial con calidad de cosa juzgada: la Administración Tributaria no puede emplear la presunción del artículo 52 para fijar que el dinero formaba parte del patrimonio de los contribuyentes, cuando el Poder Judicial declaró que el propietario era el Estado peruano

El 24 de enero del 2002, el Segundo Juzgado Penal Especial de Lima, mediante la incautación de US\$20.550.000,00, e intereses legales por liquidar, estableció cautelarmente que el dinero depositado en los Bancos Edmond de Roschild y UBS Bank de Lugano era de propiedad del Estado peruano.

El 21 de noviembre del 2003, el Segundo Juzgado Penal Especial de Lima, mediante el decomiso de US\$21.155.173,55, se los entregó a su propietario, el Estado peruano, de manera definitiva. Ni siquiera tuvo que esperar a la conclusión del proceso penal y a la expedición de una sentencia condenatoria al aplicar el Decreto de Urgencia 122-2001, vigente a la fecha de expedición del auto de decomiso.

La sentencia condenatoria del 16 de mayo del 2005, como correspondía, ya no decomisó los fondos públicos apropiados por el peculado, los sobornos recibidos por el cohecho pasivo propio, ni las ganancias que produjeron, pues, como se reitera, se habían restituido al Estado en noviembre del 2003.

El Poder Judicial dictó en ese proceso penal auto de incautación, auto de decomiso y sentencia condenatoria, que determinaron al Estado del Perú como propietario del dinero depositado en la banca suiza.

La Sunat no tenía necesidad de probar si el dinero depositado en los bancos suizos formaba parte del patrimonio de los contribuyentesdemandantes; ya el Poder Judicial había establecido que no les pertenecía al incautarlo y decomisarlo, entregándoselo a su propietario, el Estado peruano, e incluso sancionándolos por su apropiación o percepción.

Hernando Devis Echandía (1988: 205), máximo exponente latinoamericano de teoría de la prueba, establece que están exentos de prueba los hechos materia de resolución judicial que tienen calidad de cosa juzgada; el profesor colombiano califica tales casos como de falta de necesidad de prueba.

La presunción solo se emplea cuando existe necesidad de prueba y, como se insiste, en las fiscalizaciones y en los procesos contenciosos tri- 
butarios ya no era necesario probar si el dinero depositado en Suiza era incremento no patrimonial de los contribuyentes, porque ya el Poder Judicial había establecido que no, pues el propietario era el Estado, a quien se le restituyó todo lo depositado en los bancos del extranjero.

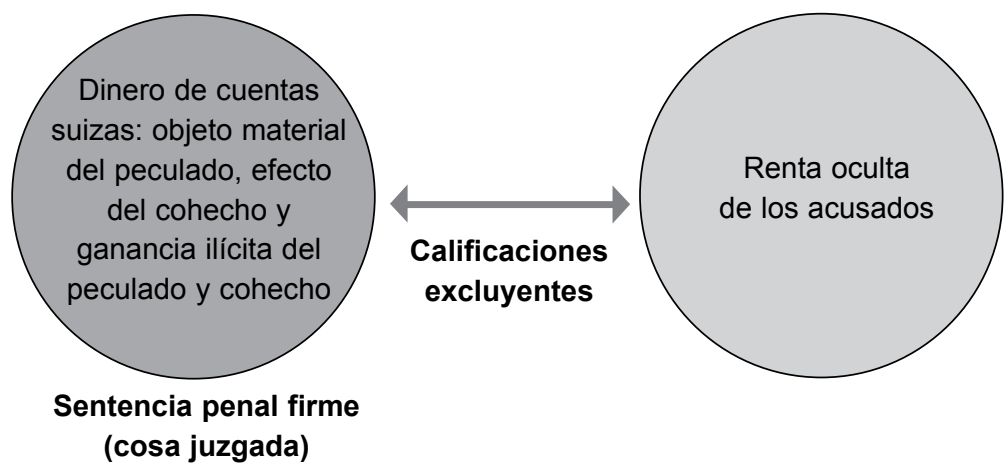

\section{El pronunciamiento del Tribunal Constitucional peruano respecto al tema en cuestión}

Nuestro Tribunal Constitucional se pronunció sobre el tema en el proceso de amparo iniciado por Nicolás Hermoza Ríos y familia contra la Sunat y el Tribunal Fiscal por haber calificado como renta presunta a los objetos, efectos y ganancias obtenidas como producto de los hechos ilícitos por los que fueron sancionados en su momento. ${ }^{8}$

En los fundamentos 7 y 8 de esa sentencia, señala como válida la aplicación de la presunción del artículo 52 de la Ley del Impuesto a la Renta:

7. A juicio del Tribunal Constitucional, para el artículo 52 antes mencionado no es relevante el origen -lícito o ilícito- del incremento patrimonial por tres razones fundamentalmente. Primero, porque de acuerdo con el artículo 74 de la Constitución no es función de la administración tributaria, ni tiene facultades para ello, determinar la procedencia lícita o ilícita de una renta específica; más aún sería absurdo

8 Sentencia del Tribunal Constitucional, del 9 de enero del 2008, expediente 049852007-PA/TC. 
y contraproducente pretender que se le exija a la administración tributaria, en casos como este, evaluar y determinar el título jurídico del incremento patrimonial.

8. Segundo, que la administración tributaria tenga que verificar previamente si el incremento patrimonial no justificado proviene de rentas lícitas o ilícitas es una exigencia irrazonable que tornaría en inviable la realización de sus facultades tributarias. En tercer lugar, porque el impuesto a la renta grava hechos o actividades económicas, no las conductas de las personas en función de si estas son lícitas o ilícitas; de lo contrario, se establecería un antecedente negativo muy grave, porque para que una persona se exima de sus obligaciones tributarias bastaría que esta alegue la ilicitud de sus utilidades; lo cual quebraría el principio constitucional tributario de igualdad (artículo 74 de la Constitución) frente a aquellas personas que cumplen, de acuerdo a ley, con sus obligaciones tributarias.

El fundamento 7 de la sentencia, o es una aplicación del derecho penal del enemigo o una muestra de lo que significa que el Tribunal Constitucional actúe sin estar integrado por especialistas de las materias objeto de los procesos constitucionales, ausencia que se nota en los hábeas corpus y en los amparos penales, que constituyen más del 50\% de la carga procesal.

El artículo 74 de la Constitución no es fundamento jurídico de la posición del Tribunal Constitucional; todo lo contrario: se trata del reconocimiento del principio de legalidad tributaria: "No hay tributo sin ley previa, clara y escrita", que exige que la descripción de los hechos económicos que generen obligaciones tributarias, esto es, el hecho imponible o la hipótesis de incidencia tributaria, tiene que estar previsto en la ley (Ataliba 1987: 66 y 67; De Juano 1969: 357 ss.).

El principio de legalidad tributaria exige, conforme al artículo 74, que exista un tipo tributario; en otros términos, una ley que defina al objeto, efectos y ganancias del delito como un hecho imponible o una hipótesis de incidencia tributaria. Por cierto, el Tribunal Constitucional no señala cuál sería la disposición de la Ley del Impuesto a la Renta que permitió a la Sunat y al Tribunal Fiscal calificar el dinero proveniente del peculado y el cohecho como renta, que, según el principio de legalidad, es la única que genera en los contribuyentes obligación tributaria. 
El Tribunal Constitucional se aparta de sus propias reglas de la motivación de las resoluciones - en este caso, constitucionales - al utilizar "motivaciones aparentes": desestima la demanda expresando que el impuesto se genera por hechos o actividades económicas y no en función de personas. ¿No leyó la demanda de amparo? ¿No fijó su objeto? Parece que el apellido Hermoza Ríos lo "desconcentró" (en la apreciación más benigna), pues nunca se postuló la arbitrariedad de la Sunat y del Tribunal Fiscal por quiénes eran los contribuyentes, sino por negarse a reconocer que el objeto, efectos y ganancias del peculado y del cohecho no forman parte del patrimonio del contribuyente $y$, por ende, no pueden ser considerados rentas y generar obligaciones tributarias.

Sobre el objeto del amparo, el Tribunal Constitucional iguardó silencio!, privándonos de la elocuencia argumentativa que se reserva para otros casos.

Sigue violando la garantía de la motivación de las resoluciones constitucionales el Tribunal Constitucional cuando sostiene que el amparo es irrazonable porque cualquier contribuyente podría sustraerse del cumplimiento de las obligaciones tributarias "alegando" el origen ilícito del dinero. Craso error: los hechos postulados se prueban, no basta afirmarlos. Y, hay que decirlo una vez más: la obligación tributaria solo se origina en hechos imponibles, hipótesis de incidencia tributaria definidas en la ley, y no existe - menos se puede inventar tácitamente - una ley en la que se defina como hecho generador de obligación tributaria a la posesión viciosa del objeto, efectos y ganancias del peculado o el cohecho.

Más infortunada es la invocación al principio constitucional de la igualdad. ¿La Sunat ha cobrado impuestos a otros delincuentes? ¿Los asaltantes, secuestradores, narcotraficantes, sicarios, etc., pagan impuesto a la renta? ¿Los fiscaliza la Administración Tributaria? ¿Siquiera lo hace, al menos, en todos los casos de peculado y cohecho? (supuesto en el que se violaría el principio de igualdad, pues, ¿por qué solamente a un tipo de delincuentes?). Por cierto, todas las respuestas son no.

La sentencia del Tribunal Constitucional es una triste demostración de violación de la Constitución por su máximo "guardián" en el Estado de derecho. No es solo su función la de interpretar. 


\section{Conclusiones}

1. Los objetos, efectos y las ganancias provenientes del delito no se convierten en renta del delincuente. Al no darse este presupuesto, esto es, al no existir renta, no se podrá configurar posteriormente un delito de defraudación tributaria que tenga como autor al delincuente poseedor vicioso del objeto, efectos y ganancias producto del delito.

2. El bien jurídico protegido por los tipos de defraudación tributaria es el adecuado funcionamiento del sistema tributario a través de la recaudación de ingresos correspondientes a obligaciones tributarias por hechos imponibles establecidos en la ley.

3. El informe técnico que emite la Sunat es una condición de la acción penal en los delitos tributarios; no es vinculante para el Poder Judicial.

4. La presunción de incremento patrimonial recogida en el artículo 52 de la Ley del Impuesto a la Renta no es aplicable a los procesos penales, pues su naturaleza, dentro del ámbito administrativo, es invertir la carga de la prueba; por tanto, es incompatible con la garantía esencial de la presunción de inocencia que rige en el ámbito penal.

5. La presunción recogida en el ámbito del artículo 52 de la Ley del Impuesto a la Renta ni siquiera en el ámbito tributario pudo ser aplicada, pues esta presunción parte de la existencia de un patrimonio - no justificado- del contribuyente, pero los objetos, efectos y ganancias del delito no forman parte nunca del patrimonio del delincuente.

6. Los objetos, efectos y ganancias del delito no se incorporan civilmente al patrimonio del delincuente, pues esa transmisión de la propiedad carece de causa justa.

7. La presunción recogida en el ámbito 52 de la Ley del Impuesto a la Renta no fue aplicable dentro del proceso penal que hemos analizado, pues contradice la prohibición de emplear una presunción para establecer un hecho que ha sido determinado ya en una resolución judicial con calidad de cosa juzgada.

8. El caso que hemos analizado constituyó, más que un error de aplicación de los conceptos civiles, tributarios y penales por parte de los principales órganos del Estado - esto es, la Sunat, el Poder 
Judicial, el Ministerio Público y el Tribunal Constitucional -, una clara decantación del propio Estado peruano por aplicar el llamado derecho penal del enemigo.

9. El derecho penal del enemigo existió y existirá en el Perú mientras los principales actores del poder no experimenten un cambio coherente en la búsqueda de darle un verdadero contenido al mandato de nuestra Norma Fundamental, que define al Perú como un Estado social y democrático de derecho.

\section{Bibliografía}

Abanto Vásquez, Manuel (2000). Derecho penal económico. Parte especial. Lima: Idemsa.

Ataliba, Geraldo (1987). Hipótesis de incidencia tributaria. Lima: Instituto Peruano de Derecho Tributario.

Bacigalupo, Enrique (dir.) (2000). Derecho penal económico. Buenos Aires: Hammurabi.

Bajo Fernández, Miguel y Silvina Bacigalupo (2001). Derecho penal económico. Madrid: Centro de Estudios Ramón Areces.

Blasco Delgado, Carolina (1997). Los incrementos y disminuciones de patrimonio sobre la renta de las personas físicas. Valladolid: Lex Nova.

Borda, Guillermo (1984). Tratado de derecho civil - Derechos reales. Tomo II. Buenos Aires: Perrot.

Boza Dibós, Beatriz (1989). "Sistema de transferencia adoptado por el legislador peruano de 1984", en Avendaño Valdez, Jorge. Derechos reales. Materiales de enseñanza para el estudio del libro $V$ del Código Civil. 2. a edición. Lima: Pontificia Universidad Católica del Perú.

Bustos Ramírez, Juan (1986). Manual de derecho penal. Parte especial. Barcelona: Ariel.

Castillo Alva, José Luis (2001). Las consecuencias jurídico-económicas del delito. Lima: Idemsa.

Cervini, Raúl (2010). “Legitimación del derecho penal tributario en el Estado social democrático de derecho". Gaceta Penal y Procesal Penal. Tomo 18.

De Juano, Manuel (1969). Curso de finanzas y derecho tributario. Parte general. 2. ${ }^{a}$ edición. Rosario: Molachino. 
Devis Echandía, Hernando (1988). Teoría general de la prueba judicial. Tomo 1. Buenos Aires: Zavalía.

Díez-Picazo, Luis (1996). Fundamentos de derecho civil patrimonial. Volumen I. 5. ${ }^{a}$ edición. Madrid: Civitas.

Eseverri Martínez, Ernesto (1995). Presunciones legales y derecho tributario. Madrid: Instituto de Estudios Fiscales - Marcial Pons/ Ediciones Jurídicas.

García Cavero, Percy (2007). Derecho penal económico. Parte especial. Lima: Grijley.

Gracia Martín, Luis (2004). Estudios de derecho penal. Lima: Idemsa.

- (2000). Lecciones de consecuencias jurídicas del delito. 2. ${ }^{\mathrm{a}}$ edición. Valencia: Tirant lo Blanch.

Jiménez Compaired, Ismael (1996). Los incrementos no justificados en el patrimonio en el impuesto sobre la renta de las personas físicas. Madrid: Marcial Pons.

Jiménez de Asúa, Luis (1992). Tratado de derecho penal. Tomo II. 5. a edición. Buenos Aires: Losada.

—. (1992b). Tratado de derecho penal. Tomo III: El delito. Buenos Aires: Losada.

Maurach, Reinhart; Gôssel, Karl Heinz y Heinz Zipf (1994). Derecho

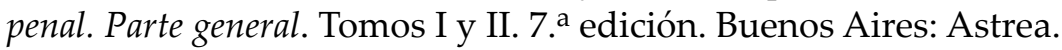

Messineo, Francesco (1971). Manual de derecho civil y comercial. Tomo VI. Buenos Aires: EJEA.

Montañés Pardo, Miguel Ángel (1999). La presunción de inocencia. Análisis doctrinal y jurisprudencial. Pamplona: Aranzadi.

Montero Aroca, Juan (1997). Principios del Proceso Penal. Una explicación basada en la razón. Valencia: Tirant lo Blanch.

Nakazaki Servigón, César Augusto (2003). “El antejuicio y la responsabilidad solidaria de los ministros de Estado respecto del delito cometido por el presidente de la República". Dialogo con la Jurisprudencia. Tomo 57.

Nakazaki Servigón, César Augusto (1988). “Proceso de elaboración de la ley penal". Tesis para optar el grado de bachiller en derecho. Lima: Universidad de Lima. 
Peris Riera, Jaime Miguel y Cristina Pla Navarro (2000). "Artículo 129", en Cobo del Rosal, Manuel (dir.). Comentarios al Código Penal. Tomo IV. Madrid: Edersa.

Polaino Navarrete, Miguel (2000). El injusto típico en la teoría del delito. Buenos Aires: Mave.

Quintero Olivares, Gonzalo; Morales Prats, Fermín y José Miguel Prats Canut (2000). Manual de derecho penal. Parte general. 2. a edición. Navarra: Aranzadi.

Rancaño Martín, María Asunción (1997). El delito de defraudación tributaria. Madrid: Marcial Pons.

San Martín Castro, César (2003). Derecho procesal penal. Tomo I. 2. ${ }^{a}$ edición. Lima: Grijley.

Simón Acosta, Eugenio (1998). El delito de defraudación tributaria. Pamplona: Aranzadi.

Zaffaroni, Eugenio Raúl (1983). Tratado de derecho penal. Parte general. Volumen 5. Buenos Aires: Ediar. 